\title{
Host Body Size, Prevalence, and Breeding Season of the Microparasitic Snail Pelseneeria castanea on the Sea Urchin Strongylocentrotus nudus in Coastal Waters of the Sea of Japan off Western Hokkaido, Japan
}

\author{
川井唯史 ${ }^{1) *}$ ・長澤和也 ${ }^{2)}$ \\ 1) 北海道原子力環境センター。 \\ 2) 広島大学生物圈科学研究科. $\bar{\tau} 739-8528$ 東広島市鏡山 1-4-4
}

\section{Tadashi KAWAI ${ }^{1) *}$ and Kazuya NAGASAWA ${ }^{2)}$}

1) Hokkaido Nuclear Energy Environmental Research Center. 261-1 Miyaoka, Kyowa, Hokkaido 045-0123, Japan

2) Hiroshima University, Graduate School of Biosphere Science. 1-4-4 Kagamiyama, Higashi-Hiroshima 739-8528, Japan

\begin{abstract}
Pelseneeria castanea is a small parasitic snail found on the sea urchin Strongylocentrotus nudus in Japan. From 100 to 282 individuals of $S$. nudus were collected at intervals of one to four months from June, 2001, to September, 2003, in coastal waters of the Sea of Japan at Tomari in the Shiribeshi District of western Hokkaido, Japan, in order to determine the body size and age of infected hosts, the breeding season of $P$. castanea, and annual and seasonal changes in infection level. Snails were observed only on small-sized $S$. nudus of less than $50 \mathrm{~mm}$ in test diameter. Infected hosts were all one or two years old in 2001 and one to four years old in 2002. No snails were found on urchins aged three to eight years hosts in 2001, nor on those aged five to eight years in 2002. It thus appears that $P$. castanea infects smaller and younger $S$. nudus and induces the mortality of infected hosts. The highest prevalences of infection each year were $94.7 \%$ in September, 2001, 16.4\% in November, 2002, and 10.6\% in June, 2003. Mean intensity of infection sharply increased in spring and summer and reached the highest level in autumn, but declined abruptly in early winter to the lowest level in late winter. Frequency of occurrence of urchins with snail egg capsules showed a similar trend. Egg capsules were most frequently found from August to November, which indicates that this is the breeding season of $P$. castanea.
\end{abstract}

Key Words: breeding season, Hokkaido, parasitic snail, Pelseneeria castanea, prevalence, sea urchin, Strongylocentrotus nudus

\section{はじめに}

北海道日本海沿岸の岩礁地帯の生物群集において, キ夕 ムラサキウニ Strongylocentrotus nudus は, 底生動物群集の 現存量に占める比率が高く, 本種を除去した後に大型海藻 群落が新しく形成された報告がある（吾妻 1997）。当地区 における大型海藻群落は, 群落外之比べて海藻と底生動物 の種多様性が高い（斉藤ら 2002）。そのためキタムラサキ ウニの生存や生長に影響する要因を解明することは岩礁生 態系の理解にとって重要である.

クリイロヤドリニナPelseneeria castanea は殸長 $4 \mathrm{~mm}$ ほどで前鰓亜綱翼舌目八ナゴウナ科に属し（堀 2000），九

Received 12 Jan. 2006 Accepted 24 May 2006

*: Corresponding author
州から相模湾に分布しアカウニPseudocentrotus depressus を宿主にすることが報告されていたが（奥谷 1986），近年 は北海道日本海南西部や岩手県・福島県沿岸での分布とキ タムラサキゥニとエゾバフンゥニS. intermedius での寄生 が新しく報告されている（藤田 2004; 川井・吾妻 1994; 武 蔵・波部 1991; 渡島西部地区水産技術普及指導所・波部 1992). 本種は主にキタムラサキゥニの反口部に寄生し, 宿 主の成長に障害を与えている（武蔵ら 1997; 武蔵・波部 1991）。しかし, 本種に関する知見の多くは初期発生, 分 布, 分類であり（網尾 1959，1963; Habe 1953）, 同属異種に 関しても知見は浮遊幼生の行動や寄生貝の付着部位等に限 られている (Bingham \& Young 1993; Koehler \& Vaney 1908). そのためクリイロヤドリ二ナの寄生率と繁殖期を 明らかにした研究は見当たらない. 本研究では北海道日本 海南西部で定期的な調査を行い, クリイロヤドリニナの宿 主の体サイズ, 年齢別の寄生率と平均寄生数, 寄生率の推 
移，繁殖期の年変動を明らかにした.

\section{材料と方法}

調查場所は北海道日本海南西部の岩内湾に位置して, 外 洋に面した泊村盃興志内地区とした（北緯 $42^{\circ} 6^{\prime} 13^{\prime \prime}$, 東経 $\left.140^{\circ} 27^{\prime} 34^{\prime \prime}\right)$. 当地区は水深の範囲が $1 \sim 6 \mathrm{~m}$ で, 主な底質 は岩盤であり直径 $1 \mathrm{~m}$ 以上の転石が点在し, $7 \mathrm{~m}$ 以深は底 質が砂となり，キタムラサキゥニがほとんど見られない。 また植生としては，ホソメコンブ Laminaria religiosa が優 占する海藻群落が水深 0 0.5 m だけで認められ, それ以 深は無節サンゴモが優占した。

調查は 2001 年 6 月 21 日〜2003年 9 月 10 日にかけて, 1 4 カ月に 1 回の頻度で行った. キタムラサキゥニの分布 の予備調査によると, 水深 0 $6 \mathrm{~m}$ における $1 \mathrm{~m}$ ごとの各 水深帯において, 本種の密度は各季節において 3 9 個体/ $\mathrm{m}^{2}$ と同様であり，水深や季節に伴う大きな変化は見られ なかった。同様に, 予備調査によるとクリイロヤドリニナ の寄生率も水深により大差は見られなかった。 そこで各調 查では水深 0 6 $\mathrm{m}$ において, 水深 $1 \mathrm{~m}$ ごとに $1 \mathrm{~m}^{2}$ の方 形枠を 3 力所以上，任意に設置して行った.

武蔵ら (1997) によるとクリイロヤドリニナの寄生は, 殼経 $50 \mathrm{~mm}$ 末満の小型のキタムラサキゥニに見られる. そのためクリイロヤドリニ+の寄生数, 平均寄生数の推移 を求めるためには，大型のキタムラサキゥ二を除外して， クリイロヤドリニナの寄生の対象之なる体サイズである殸 径 $50 \mathrm{~mm}$ 未満の個体が 30 個体程度集まるように設定する のが望まれた。 そして予備調査により調查海域におけるキ ラムラサキゥニの款経組成を求めたところ，30４0\% の個 体が殼経 $50 \mathrm{~mm}$ 未満であった。 そのため小型個体を 30 個 体程度採集するためには，少なくとも100 個体以上のキ夕
ムラサキゥニを採集することが必要となる．また，荒天時 の数日後に行った予備調查では, キタムラサキウニが転石 の下や岩盤の亀裂の深い場所に隠れてしまうためか, 密度 が一時的に低下した。 また当調查地区では，殼経 $5 \mathrm{~cm}$ 以 上のキラムラサキウニが 5 8月に, 1〜2回漁獲されるの で, 漁期後は大型の個体が一時的に減少する。 そこで設置 する方形枠の個数は 10 地点以上とし, 各調查でそれぞれ 合計 100 個体以上のキタムラサキゥニを採集し, 殼経 50 $\mathrm{mm}$ 未満の個体を 30 個体程度確保した。

得られたキタムラサキゥニの殼径を測定し, クリイロヤ ドリニナの寄生数を計数し，その卵襄の付着の有無を記録 した後, 調査場所外に放流した. 卵衰は過去の知見 (Habe 1953）を参考にして有無を判別した。また 2001 年 10 月 25 日と 2002 年 11 月 6 日に採集したキタムラサキゥニは川村 (1973) と Jensen (1969) の方法に従って年齢を查定し, 生 殖板の外面にあるイボがなくなるまで砥石で研磨した後 に，アルコールランプで加熱し，キシロールで透化する方 法をとった。 また泊村近郊に位置する乙部町では 9 月にキ 夕ムラサキゥニの発生初期段階の浮遊幼生が採集されてい る（吾妻 1997）。そこで9月を産卵期として満年齢として 求めた。

用語は Bush et al. (1997) に従い, 寄生率 (prevalence) $(\%)=($ 被寄生個体総数/採集個体総数) (percentage of infected hosts in a sample) $\times 100$, 平均寄生数 (mean intensity) $=$ 付着していた寄生貝総数/被寄生個体総数 (mean number of parasites per infected host) とした。 その他にク リイロヤドリニナの産卵期を求めるため, 卵出現頻度 $(\%)$ を, (卵囊の付着が観察された宿主数/被寄生個体数) $\times 100$ で示した，年齢別寄生率 (\%) は，（各年齢の被寄生個体総 数/各年齢の採集個体総数 $) \times 100$ とした.

Table 1. Test diameter ( $\mathrm{mm}$ ) of sea urchins, Strongylocentrotus nudus, including those infected with microparasitic snails, Pelseneeria castanea (left), all sea urchins (right), and smaller $S$. nudus of less than $50 \mathrm{~mm}$ in test diameter (center).

\begin{tabular}{|c|c|c|c|c|c|c|c|c|c|c|c|c|c|c|}
\hline & \multirow{2}{*}{\multicolumn{2}{|c|}{ Date }} & \multicolumn{4}{|c|}{ Infected $S$. nudus } & \multicolumn{4}{|c|}{ Smaller $S$. nudus } & \multicolumn{4}{|c|}{ All $S$. nudus examined } \\
\hline & & & Mean & SD & Range & Number & Mean & SD & Range & Number & Mean & SD & Range & Number \\
\hline 21 & June & 2001 & 34.9 & 4.0 & $27.8-39.4$ & 6 & 37.1 & 4.3 & $20.7-48.7$ & 196 & 38.7 & 6.5 & $20.7-61.8$ & 223 \\
\hline 03 & Aug. & 2001 & 33.0 & 2.6 & $29.5-36.1$ & 9 & 35.3 & 4.4 & $28.0-49.6$ & 41 & 56.6 & 13.0 & $28.0-75.6$ & 196 \\
\hline 28 & Sep. & 2001 & 29.5 & 7.3 & $18.8-40.2$ & 18 & 32.0 & 7.2 & $18.8-43.0$ & 19 & 49.7 & 13.5 & $18.8-60.0$ & 108 \\
\hline 25 & Oct. & 2001 & 34.9 & 5.7 & $20.1-47.3$ & 32 & 34.7 & 7.0 & $13.4-47.3$ & 68 & 34.7 & 7.0 & $13.4-47.3$ & 100 \\
\hline 01 & Dec. & 2001 & 30.4 & 5.9 & $18.5-41.4$ & 32 & 35.4 & 7.4 & $13.7-49.9$ & 124 & 36.7 & 8.6 & $13.7-58.2$ & 167 \\
\hline 26 & Jan. & 2002 & 28.4 & 7.6 & $21.1-39.7$ & 7 & 30.3 & 6.5 & $21.1-49.1$ & 31 & 48.5 & 12.3 & $21.1-57.5$ & 132 \\
\hline 16 & Mar. & 2002 & 30.3 & 4.9 & $26.1-43.1$ & 13 & 37.0 & 7.0 & $21.3-48.9$ & 110 & 37.7 & 7.7 & $21.3-59.2$ & 129 \\
\hline 25 & Apr. & 2002 & 40.4 & 4.1 & $36.6-45.7$ & 4 & 37.0 & 5.8 & $26.0-49.9$ & 79 & 41.4 & 10.1 & $26.0-71.1$ & 107 \\
\hline 13 & July & 2002 & 36.3 & 3.3 & $31.0-42.6$ & 20 & 39.0 & 5.5 & $15.5-49.3$ & 143 & 41.3 & 7.9 & $15.5-66.1$ & 190 \\
\hline 06 & Nov. & 2002 & 29.4 & 8.9 & $19.0-47.4$ & 31 & 35.5 & 10.5 & $13.4-49.2$ & 189 & 35.5 & 10.5 & $13.4-49.2$ & 220 \\
\hline 05 & Feb. & 2003 & 40.9 & 2.5 & $39.1-42.7$ & 2 & 40.8 & 5.4 & $24.3-49.2$ & 45 & 49.5 & 9.4 & $24.3-66.2$ & 102 \\
\hline 08 & May & 2003 & 40.5 & 4.8 & $37.0-46.0$ & 3 & 41.5 & 5.4 & $30.0-49.8$ & 70 & 47.1 & 9.0 & $30.0-73.5$ & 118 \\
\hline 26 & June & 2003 & 35.8 & 5.9 & $26.8-42.8$ & 11 & 36.3 & 5.3 & $26.2-49.8$ & 104 & 37.1 & 6.3 & $26.2-54.0$ & 121 \\
\hline 02 & July & 2003 & 37.8 & 7.5 & $29.5-49.8$ & 6 & 38.1 & 5.3 & $26.5-49.8$ & 166 & 44.9 & 10.4 & $26.5-79.8$ & 282 \\
\hline 10 & Sep. & 2003 & 43.5 & 8.6 & $37.4-49.5$ & 2 & 35.6 & 9.8 & $10.0-49.6$ & 36 & 46.9 & 9.6 & $10.0-54.0$ & 120 \\
\hline
\end{tabular}




\section{結果}

1 回の調査ごよに，採集されたキタムラサキウ二全個体 の平均殸径之最大殼径を求めた。 各調査において, 平均殼 径は $34.7 \sim 56.6 \mathrm{~mm}$, 最大殼径は $47.3 \sim 79.8 \mathrm{~mm}$ の範囲て 推移した。クリイロヤドリ二ナの寄生を受けたキタムラサ キゥ二も同様に調查ごとに殼径の平均值と最大值を求めた ところ, 平均殼径 $28.4 \sim 43.5 \mathrm{~mm}$, 最大殼径 $36.1 \sim 49.8 \mathrm{~mm}$ で推移した (Table 1). クリイロヤドリニナの寄生が見ら れた宿主は比較的殼径が小さく, 殼径 $50 \mathrm{~mm}$ 未満の個体 に限られた。そこで，クリイロヤドリ二ナの寄生が見られ るのは款径 $50 \mathrm{~mm}$ 未満の個体に限られる之仮定し,この 殼径の個体を対象に年齢別の寄生率・平均寄生数, 寄生率 の推移, 平均寄生数の推移, 産卵時期を求めた。

採集年別, 年齢別の寄生率を Fig. 1 に示した。得られた 殼径 $50 \mathrm{~mm}$ 未満の個体の年齢構成は, 2001 年が 1 3 歳, 2002 年が 1 8 歳であった。しかし寄生を受けたキ夕ムラ サキウニは比較的若齢の個体であり, 2001 年は 1 2 歳,

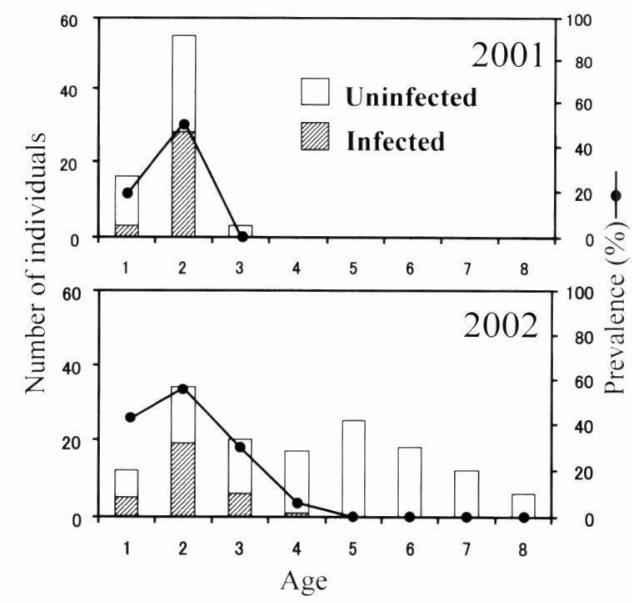

Fig. 1. Variation in prevalence of infection of Pelseneeria castanea on Strongylocentrotus nudus of different ages collected in coastal waters of the Sea of Japan at Tomari, western Hokkaido, Japan, in 2001 and 2002.

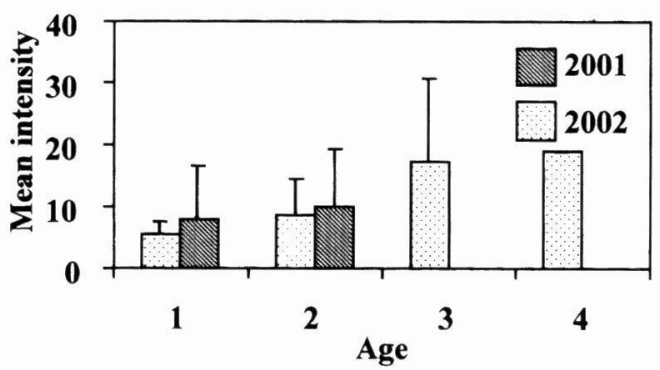

Fig. 2. Variation in mean intensity of Pelseneeria castanea on Strongylocentrotus nudus of different ages collected in coastal waters of the Sea of Japan at Tomari, western Hokkaido, Japan, in 2001 and 2002. Vertical bars represent standard deviations.

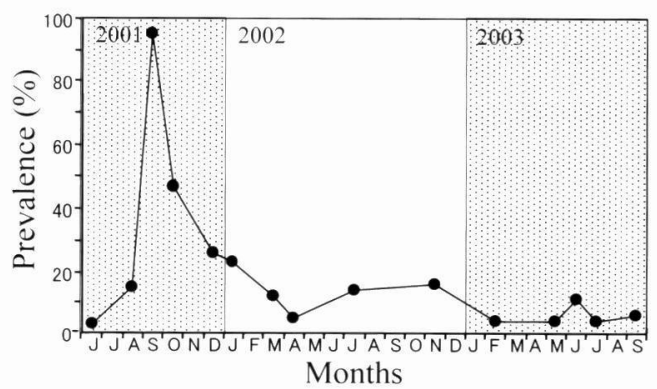

Fig. 3. Seasonal changes in prevalence of infection of Pelseneeria castanea on Strongylocentrotus nudus in coastal waters of the Sea of Japan at Tomari, western Hokkaido, Japan, from June, 2001, to September, 2003.

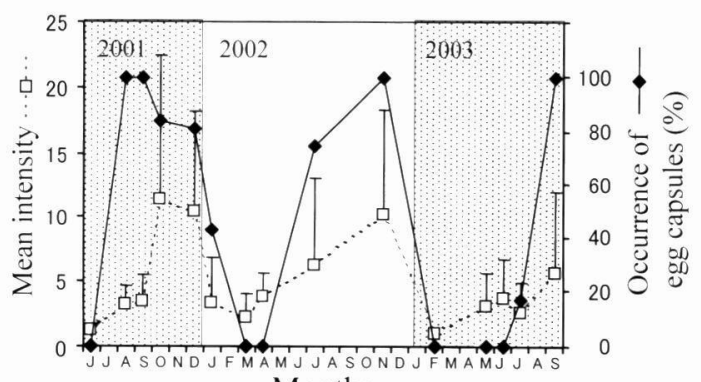

Months

Fig. 4. Seasonal changes in mean intensity of Pelseneeria castanea on Strongylocentrotus nudus and in frequency of occurrence of $S$. nudus with egg capsules of $P$. castanea in coastal waters of the Sea of Japan at Tomari, western Hokkaido, Japan, from June, 2001, to September, 2003. Vertical bars represent standard deviations.

2002 年が $1 \sim 4$ 歳に限られた。寄生率を年齢構成, 調査年 別に比較すると，2001 年は 1 歳が $18.8 \%, 2$ 歳が $50.9 \%$ に 寄生が見られ，3歳では寄生率は $0 \%$ だった。 2002 年の寄 生率は，1歳が $41.7 \%, 2$ 歳が $55.9 \%, 3$ 歳が $30.0 \%, 4$ 歳 が 5.9\%, 5 歳以上では寄生が見られなかった. 寄生率が最

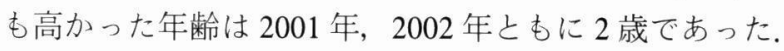

平均寄生数は, 2001 年之 2002 年ともにキタムラサキウ 二の年齢が増すとと屯に増加する傾向が見られた (Fig. 2).

寄生率の月別変動を見ると, 2001 年 6 月の $3.1 \%$ 加急 激に上昇し，9月に $94.7 \%$ となった (Fig. 3). その後, 寄生 率が低下して 2002 年の 3 7 月にかけて 5.1 14.0\% で推 移した。同年の 11 月には寄生率が $16.4 \%$ となったが，そ の後, 低下して 2003 年 2 月以降は $10.6 \%$ 以下で推移し た.

一方, 平均寄生数は顕著な季節变動を示した (Fig. 4). 2001 年 6 月の 1.2 加ら急激に上昇し 8 月にピークの 11.4 となり, 2002 年 3 月の 2.2 まで低下した。 その後, 再び上 昇し 11 月にピークの 10.2 を示した後, 2003 年 2 月の 1.0 まで低下して，9月の 5.5 まで上昇した。

クリイロヤドリ二ナの卵出現頻度も同様に大きな季節変 動を示し (Fig. 4), 2001 年6月の $0 \%$ から 8 月月の 
$100 \%$ まで上昇し, 2002 年 3 4 月の $0 \%$ まで低下した。 そ の後, 上昇して 2002 年 11 月の $100 \%$ がピークで, 再び低 下して 2003 年 2～6月の $0 \%$ となり，また上昇して 9 月に は $100 \%$ となった。

平均寄生数と卵出現頻度の推移は極めて類似し, 年間最 低值と最高値を示す月がほぼ同様であり, 2001 年の最高値 を示す月だけが 1 力月間ずれた。最高值は 2001 年に 11.4 , 2002 年に 10.2 で, 最低值も 2002 年に 2.2 で 2003 年に 1.0 でと, それぞれ同様であり, 平均寄生数の年間最低・最高 値は大きな年変動が見られなかった。卵出現頻度の最低・ 最高值も, 調查期間中に年変動を示さなかった. 2001 年, 2002 年, 2003 年と屯に, 最高值が $100 \%$, 年間最低值が 0\%であった.

\section{考 察}

岩手県沿岸においてクリイロヤドリニナの寄生を受けた キタムラサキゥ二の壳径は $50 \mathrm{~mm}$ 未満の比較的小型の個 体が中心であり（武蔵ら 1997），これは本研究結果と同様 である。これまでの研究に基づくと, クリイロヤドリ二ナ の寄生が見られるキタムラサキゥニが小型の個体に限られ る理由として, いくつかの可能性を提示できる. その一つ として, 宿主となった個体の殼径の成長が寄生により抑制 され，小型のまま加齢していることが考えられる. しかし 本研究により, クリイロヤドリニナの寄生を受けていたキ タムラサキウニは, 比較的若齢の個体に限られることが確 かめられた。このため, 寄生を受けたキ夕ムラサキウニが 小型のまま加齢している可能性は乏しい.

他の可能性として, 宿主が加齢する前に死亡している可 能性, あるいは寄生を受けた個体が加齢に伴いクリイロヤ ドリニナが消失している可能性がある. 本研究では宿主の 加齢に伴い, 平均寄生数が増大する傾向が観察された。武 蔵ら (1997) は, 岩手県沿岸でクリイロヤドリニナの寄生 によるキタムラサキゥニへの影響を体サイズ別に比較し た. その結果, 被寄生個体は, 殼径が大きくなるに従い, 殼高/殼径の割合が低くなり殼の变形の度合いが高くなる こと, また生殖巣の発達も抑制されること, さらに殸径が 大きくなるに従って平均寄生数が多くなることが確かめら れた。本研究と武蔵ら (1997) の研究の結果を考え合わせ ると, クリイロヤドリニナに感染した個体は, 寄生による 悪影響を受けると考えることができる。そしてクリイロヤ ドリニナの寄生を受けた比較的小型の個体は, 加齢に伴い 寄生貝が消失するのではなく, 寄生を受けてからの時間が 経過するに伴って寄生による悪影響が大きくなり, 死亡し ている可能性があると思われる. 今後は加齢に伴い, 寄生 を受けた個体が死亡している可能性に関して室内試験で検 証することが望まれる.

2001 年に寄生率の大きなピークが認められたが，2002 年と 2003 年には認められなかった (Fig. 3). 今のところ,
その原因は不明であるが, 2001 年 9 月前後はクリイロヤド 二ナがキタムラサキウ二に広く感染しやすい何らかの条件 があったと考えられる. 今後は, クリイロヤドリニナが生 活環のどの段階で, どのようにキタムラサキゥニに感染す るかについて明らかにし, 感染しやすい環境条件について 検討する必要である。

寄生率と平均寄生数はともに夏季がピークとなり, 秋季 から冬季にかけて急激に低下する傾向が認められた (Figs. 3, 4). この理由としては, 少なくとも二つの可能性が提示 でき，一つはクリイロヤドリ二ナの平均寄生数が上昇した 影響でキタムラサキウ二が死亡していることが考えられ る. あう一つの可能性としては, 秋季加ら冬季にかけて産 卵を終えたクリイロヤドリニナが寿命となり死亡している ことも考えられる. 本研究結果の範囲内では, 寄生率と平 均寄生数が秋季から冬季にかけて低下する原因は明らかに できない。これを明らかにするために，野外においてクリ イロヤドリニナの成長式と寿命を求め, さらに寄生を受け たキタムラサキゥニを室内水槽で飼育して死亡の有無を観 察することが望まれる.

宿主が死亡したときにおける，付着していたクリイロヤ ドリニナの動向について, 秋季に寄生率が低下したことと 関連させて考察する.クリイロヤドリニナがキタムラサキ ウニに付着した部位には寄生痕が見られ, 時には宿主の体 腔内に達する孔があるので（武蔵ら 1997），クリイロヤド リニナの定着性は極めて高いものと思われる。 またクリイ ロヤドリニナの近縁種の多くは, 足 footが退化的であり, 移動能力が乏しいことが指摘されている (Koehler \& Vaney 1908). そのためクリイロヤドリニナも同様に移動能 力が乏しいと思われ，仮に宿主が秋季に死亡しても，遠く に離れた別の宿主まで移動して新しく付着する能力に乏し いと思われる。 また網尾 (1959) は, 成貝のクリイロヤド リニナが水面を浮遊すると記述している。 しかし，キタム ラサキゥ二は海底に生息するので，成貝のクリイロヤドリ 二ナが宿主を離れて水面を浮遊し, 新しい宿主に付着でき る可能性が高いとは考えにくい. 以上のことから, 宿主が 死亡した場合, 付着していたクリイロヤドリニナは, 容易 に新しい宿主へ移動できることはないと考えられ，宿主の 死亡が同時期に発生すると, 寄生率は低下すると思われ る. 秋季に寄生率が低下した傾向の説明の一つとして, 前 述のように宿主が死亡している可能性が指摘されている. クリイロヤドリニナは宿主が死亡しても新しい宿主に移動 できる能力が乏しいと思われるので, 秋季において死亡が 発生しているとの可能性と秋季における寄生率の低下に は, 整合性がある。

本種の繁殖時期について検討する. 網尾 $(1959,1963)$ は クリイロヤドリニナの卵裹内にあった発生初期である 4 細 胞期の受精卵を飼育し, 飼育開始から 12 13 日後に被面 子幼生が卵囊から泳ぎ出るのを観察した。このことは卵囊 が生み出されてから比較的短期間で幼生が稱出することを 
意味している．本種の被面子幼生は殼高 $0.4 \mathrm{~mm}$ ほどの殼 を有した大型の幼生として卵裹加ら放出され，幼生には遊 泳器官が観察されないことから (Habe 1953), 本種の浮遊 期間は極めて短いものと思われる．またクリイロヤドリニ ナが属するハナゴウナ科の各種の巻貝類の殼頂部に存在す る幼殼の巻き数は, 浮遊幼生の期間の長さと対応している (Bouchet \& Warén 1979). 本種の幼殼の巻き数は 1 前後で あり (Habe 1953), 同科の他種は巻き数が 2 以上であり, これらと比較しても巻き数が少ない (Warén 1983, 1984). このことは，クリイロヤドリニナの浮遊幼生期間が短いと の考えを補足している. 室内水槽での初期発生観察や幼殼 の形態観察の結果 (Bouchet \& Warén 1979; Habe 1953) に 基づくと，クリイロヤドリニナの卵が生み出されてから睬 化して浮遊生活を送った後, 宿主に付着するまでの期間は 極めて短いと考えられる. また本研究において, 卵囊の出 現頻度が年間で最高值を示した月と寄生率が年間最高値で あった月は，ともに8〜11月であった。これらのことを考 え合わせると, 北海道日本海南西部のクリイロヤドリニナ において, 卵裹が生み出され幼生が孵化し加入が起こる繁 殖期は, 晚夏から秋の 8 11 月と思われる.

謝辞：調查にご理解とご協力いただいた盃漁業協同組合，潜水 調査にご協力をいただいた北海道原子力環境センターの各位，研 究へ親切なご助言をいただいた神尾道也, 波部忠重, 長谷川和範, 松田春菜, 馬渡駿輔, 武蔵達也, 文珠正折をはじめとする各氏に深 謝します。

\section{引用文献}

吾妻行雄 1997. キタムラサキゥ二の個体群動態に関する生態学 的研究. 北海道立水産試験場研究報告, 51: 1-66.

網尾 勝 1959. 海産腹足類の卵仔に関する研究一II. ヒメムシロ 他 6 種. 農林省水産講習所研究報告, 8: 73-83.

網尾 勝 1963. 海産腹足類の比較発生学ならびに生態学的研究. 水産大学校研究報告, 12: 229-358.

Bingham, B. L. and C. M. Young 1993. Larval phototaxis in barna- cles and snails associated with bathyal sea urchins. Deep-Sea Research I, 40: 1-12.

Bouchet, P. and A. Warén 1979. Planktotrophic larval development in deep-water gastropods. Sarsia, 64: 37-40.

Bush, A. O., K. D. Lafferty, J. M. Lotz and A. W. Shostak 1997. Parasitology meets ecology on its own terms: Margolis et al. revisited. Journal of Parasitology, 83: 575-583.

藤田恒雄 2004. 福島県いわき沿岸でみられた寄生性巻貝クリイ ロヤドリニナ。福島県水産試験場研究報告, 12: 27-29.

Habe, T. 1953. Studies on the eggs and larvae of the Japanese gastropods (4). Publications of the Seto Marine Biological Laboratory, 3: 161-173.

堀 成夫 2000 . 日本近海産貝類図鑑. 東海大学出版会, 奥谷喬司 編, 東京, $1173 \mathrm{pp}$.

Jensen, M. 1969. Age determination of echinoids. Sarsia. 37: 41-44. 川井唯史・吾妻行雄 1994. 北海道後志沿岸に打ける寄生貝クリ イロヤドリニナの分布と出現状況. 栽培漁業技術開発研究, 23: 7-9.

川村一廣 1978. エゾバフンウ二の漁業生物学的研究. 北海道立水 産試験場研究報告, 16: 1-54.

Koehler, R. and C. Vaney 1908. Description d'un nouveau genre de Prosobranches parasite sur certains Échinides. Bulletin de l'Institut Oceanographique, 118: 1-16.

武蔵達也・波部忠重 1991. クリイロヤドリ二ナの新分布地と新 宿主.ちりぼたん, 22: 69-71.

武蔵達也・西洞考広・内田 務 1997. 岩手県沿岸に抢ける寄生 具クリイロヤドリニナがキタムラサキゥニに与える影響. 岩手 祘水産技術センター研究報告, (1): 27-35.

奥谷喬司 (編著) 1986. 生物大図鑑 貝類. 世界文化社, 東京, 399 pp.

渡島西部地区水産技術亚及指導所・波部忠重 1992 . 北海道渡島 半島松前町でもキタムラサキゥニに寄生貝. ちりぼたん， 22: 93.

斎籐暢宏・金个友美・川嶋昭二・角田博義・新井章吾・四ッ倉典 濼・川井唯史 2003. 北海道日本海南西部岩内のホソメコンブ 群落に出現した海藻類とその葉上動物. 日本ベントス学会誌, 57: 43-53.

Warén, A. 1983. A generic revision of the family Eulimidae. Journal of Molluscan Studies, Supplement 13: 1-92.

Warén, A. 1984. Description of five new species of Hawaiian Eulimidae. Veliger, 26: 170-178. 